\title{
Recurrent Chromophobe Renal Cell Carcinoma
}

National Cancer Institute

\section{Source}

National Cancer Institute. Recurrent Chromophobe Renal Cell Carcinoma. NCI Thesaurus.

Code C153595.

The reemergence of chromophobe renal cell carcinoma after a period of remission. 